\title{
List of documents
}

1. Muhammad 'Abd al-Rahīm to Jean-Baptiste Coulbeaux

[Jan. 1880]

2. 'Abd al-Karīm to Jean-Baptiste Coulbeaux

19 Jan. 1880

3. Mihiret Haylu to "friends in Sweden"

17 Feb. [1880]

4. Convention between Burhān Muhammad and Rubattino Co.

15 March 1880

5. Yohannis IV to Victoria

29 April 1880

6. Yohannis IV to the British government

29 April 1880

7. Adal Tesemma to Abba Rago

[April 1880]

8. Declaration by Afar chiefs re territory at Aseb

15 May 1880

9. Convention between Afar chiefs and the Rubattino Co.

15 May 1880

10. Minilik II to Victoria

3 June 1880

11. Minīlik II to Giuglielmo Massaja

11 June 1880

12. Alula Ingida Qubī to Erik Emil Hedenström

18 June 1880

13. Convention between Burhān Muhammad and Giuseppe Sapeto

20 Sept. 1880

14. Burhān Muhammad to Giuseppe Sapeto

[20] Sept. 1880

15. Minìlik II to Antonio Cecchi

6 Oct. 1880

16. Minīlik II to Onorato Caetani

17. Minīlik II to Jules Grévy

16 Oct. (?) 1880

18. Minīlik II to Albert Delagenière

1 Nov. 1880

19. Ratification by 'Abdallah Shahīm of 15 May 1880 convention

1 Nov. 1880

20. Minīlik II to Benedetto Cairoli

5 Nov. 1880

21. Tekle Gīyorgīs to Kīrillus V

9 Nov. 1880

22. Alula Ingida Qubī to Gerhard Rohlfs

15 Nov. [1880?]

23. Alula Ingida Qubī to Gerhard Rohlfs

23 Nov. 1880

24. Lewțē Zewde to Gerhard Rohlfs

[Nov. 1880]

25. Alula Ingida Qubī to Achille Raffray

[Nov. 1880]

26. Gebre Igzī’ to Kīrillus V

10 Dec. 1880

27. Yohannis IV to Minīlik II

15 Dec. [1880?]

28. Gebru Abba Çhequn to Achille Raffray

16 Dec. 1880

29. Yūsif al-Anțūnī to Kīrillus V

16 Jan. [1881]

30. Yohannis IV to Wilhelm I

22 Jan. 1881

31. Yohannis IV to Otto von Bismarck

17 Feb. 1881

32. Yohannis IV, power of attorney for Gerhard Rohlfs

17 Feb. 1881

33. Yohannis IV to Gerhard Rohlfs

17 Feb. 1881

34. Abū Bakr Ibrāhīm to Jules Grévy

23 Feb. 1881

35. Alula Ingida Qubī to Kīrillus V

6 March 1881

7 March [1881?] 
36. Minīlik II to Umberto I

30 March 1881

37. Tekle Gìyorgīs to Kïrillus V

31 March [1881?]

38. Gebre Gīyorgīs to Kīrillus V

[March 1881]

39. Yohannis IV to Muhammad Tawfīq

5 April 1881

40. Yohannis IV to Muhammad Tawfīq

5 April 1881

41. Yohannis IV to Kïrillus V

5 April 1881

42. Yohannis IV to Kīrillus V

5 April 1881

43. Yohannis IV to Welde Sema'it Welde Yohannis

5 April 1881

44. Yohannis IV to the Ethiopian community in Jerusalem

5 April 1881

45. Burhān Muhammad to the Italian representative in Aseb

[22 April] 1881

46. Yohannis IV to Jean-Marcel Touvier, Jean-Baptiste Coulbeaux

19 June 1881 and Sixtus Barthèz

47. Mahammad Hanfadhē to Louis Auguste Brémond

June 1881

48. Minīlik II to Umberto I

11 July 1881

49. Minīlik II to Umberto I

12 July 1881

50. Minīlik II to Benedetto Cairoli

12 July 1881

51. Yohannis IV to Achille Raffray

17 July 1881

52. Yohannis IV to Gerhard Rohlfs

27 July 1881

53. Yohannis IV, declaration on extent of Ethiopian territory

27 July 1881

54. Burhān Muhammad, declaration on relation with Egypt

19 Aug. 1881

55. Nigusē Tasho and Amanu'ēl Hamed to Bengt Peter and Emelie Lundahl

[Aug.-Sept. 1881]

56. Welde Șadiq to Umberto I

4 Sept. [?] 1881

57. Yohannis IV to Welde Sema'it Welde Yohannis and the Ethiopian community in Jerusalem

5 Sept. 1881

15 Sept. [1881?]

58. Isțifanos Fisseha to Mekonnin

23 Sept. 1881

59. Onesimus Nesib to Johannes Neander

9 Oct. 1881

60. Minīlik II to Onorato Caetani

14 Oct. 1881

61. Minilik II to Umberto I

4 Nov. 1881

62. Yohannis IV to Victoria

4 Nov. 1881

63. Yohannis IV to Jules Grévy

6 Dec. 1881

64. Yohannis IV to Minìlik II

9 Jan. 1882

65. Lewțē Zewde to Kïrillus V

15 Jan. 1882

67. Yohannis IV to Tekle Haymanot

30 Jan. 1882

68. Yohannis IV, proclamation on the faith of ferenj

[Jan. 1882]

69. Yohannis IV, proclamation on the practice of Islam

[Jan. 1882]

70. Yohannis IV, proclamation on schismatics

[Jan. 1882] 
71. Ar'aya Sillasē Dimșu to Achille Raffray

[Jan. 1882]

72. Ar'aya Sillasē Dimṣu to Juan Víctor Abargues de Sostén

[Jan. 1882]

73. Ar'aya Sillasē Dimṣu to Juan Víctor Abargues de Sostén

[Jan. 1882]

74. Yohannis IV to Muhammad Tawfīq

14 Feb. 1882

75. Yohannis IV to Muhammad Tawfīq

16 Feb. 1882

76. Yohannis IV to Welde Sema'it Welde Yohannis and the

20 Feb. 1882 community of Dayr al-Sultan

77. Yohannis IV to Welde Sema'it Welde Yohannis and the

22 Feb. 1882 community of Dayr al-Sultan

78. Minīlik II to Jules Grévy

7 March 1882

79. Minīlik II to François Soumagne

7 March 1882

80. Minīlik II to Pierre Arnoux

7 March 1882

81. Minīlik II to Pietro Antonelli

9 March 1882

82. Welde Șadiq to Pierre Arnoux

22 March 1882

83. Gebru Abba Çhequn to François Soumagne

24. March 1882

84. Mahammad Hanfadhē to Pietro Antonelli

28 May 1882

85. Pèțros to clerics and believers in Jenda

12 June 1882

86. Yohannis IV to Minīlik II

8 July 1882

87. Minīlik II to Pēțros, Matēwos, Marqos and Luqas

11 July 1882

88. Minīlik II to Victoria

20 July 1882

89. Alula Ingida Qubī to Achille Raffray

20 July 1882

90. Yohannis IV to Achille Raffray

17 Aug. 1882

91. Yohannis IV to Gerhard Rohlfs

19 Aug. 1882

92. Hamad La'ìta to Pietro Antonelli

28 Sept. 1882

93. Yohannis IV to Umberto I

30 Sept. 1882

94. Minilik II to Paul Soleillet

9 Oct. [1882]

95. Maḥammad Hanfadhē to Sa'îd Awìdan

16 Oct 1882

96. Minìlik to Giulio Pestalozza

18 Oct 1882

97. 'Abd al-Raḥmān Yūsif to Pietro Antonelli

20 Oct. 1882

98. Maḥammad Hanfadhē to Pietro Antonelli

24. Oct. 1882

99. Maḥammad Hanfadhē to Commissario Regio in Aseb

24. Oct. 1882

100. Mahammad Hanfadhē to Giulio Pestalozza

25 Nov. 1882

101. Maḥammad Hanfadhē to Pietro Antonelli

25 Nov. 1882

102. Maḥammad Hanfadhē, power of attorney for 'Abd-al-Raḥmān

26 Nov. 1882

103. Maḥammad Hanfadhē to Pietro Antonelli

6 Dec. 1882

104. Burhān Muhammad to Giulio Pestalozza

17 Dec. 1882

105. Hamad La'îta to Giulio Pestalozza

9 Jan. [1883] 
106. Burhān Muhammad to Giulio Pestalozza

[Jan. 1883]

107. Burhān Muhammad to Pasquale Stanislao Mancini

27 Jan. 1883

108. Maḥammad Hanfadhē to Pasquale Stanislao Mancini

14 March 1883

109. Maḥammad Hanfadhē and Burhān Muḥammad to

16 March 1883

Pasquale Stanislao Mancini

110. Yohannis IV to İyasu Dagmawī

19 March 1883

111. Hamad La'ìta to Pasquale Stanislao Mancini

22 March 1883

112. Burhān Muhammad to Pasquale Stanislao Mancini

25 March 1883

113. Yohannis IV to Victoria

9 April 1883

114. Yohannis IV to Wilhelm I

9 April 1883

115. Yohannis IV to Jules Grévy

9 April 1883

116. Yohannis IV to Kīrillus V

10 April 1883

117. Maḥammad Ḥanfadhē, Burhān Muḥammad and Hamad La'īta to Giovanni Branchi and Giulio Pestalozza

14 April 1883

118. Treaty between Maḥammad Hanfadhē and Italy

18 April 1883

119. Yohannis IV to Victoria

8 May 1883

120. Yohannis IV to Edward Malet

8 May 1883

121. Onesimus Nesib to Johannes Neander

14. May1883

122. Treaty between Shewa and Italy

21 May 1883

123. Minīlik to Giulio Pestalozza

21 May 1883

124. Minīlik II to Pasquale Stanislao Mancini

21 May 1883

125. Minīlik II to Giacomo Malvano

21 May 1883

126. Nigusē Tasho et al. to Bengt Peter and Emelie Lundahl

29 May 1883

127. Yohannis IV to Demosthenes Mitzakis

30 May 1883

128. Mahammad Hanfadhē to Giulio Pestalozza

2 June 1883

129. Mirçha Werqē to Robert Fleming

12 June 1883

130. Minilik II to the Ethiopian community in Jerusalem

25 June 1883

131. Minīlik II to Umberto I

30 June 1883

132. Tamrē $A b b a$ Sebsib to Umberto I

30 June $18[83]$

133. Alula Ingida Qubī to Augustus Blandy Wylde

[June (?) 1883]

134. Alula Ingida Qubī to Augustus Blandy Wylde

[June (?) 1883]

135. Gobena Daçhī to Umberto I

3 July 1883

136. Welde Șadiq to Umberto I

10 July 1883

137. Maḥammad Hanfadhē to Pasquale Stanislao Mancini

30 July 1883

138. Maḥammad Hanfadhē to Pasquale Stanislao Mancini

21 Aug. 1883

139. Yohannis IV to Umberto I

1 Oct. 1883

140. Burhān Muhammad to Giulio Pestalozza

9 Oct. 1883 
141. Hamad La'īta to Giovanni Branchi

27 Oct. 1883

142. Tekle Haymanot to Umberto I

22 Nov. 1883

143. Tekle Haymanot to Pasquale Stanislao Mancini

22 Nov. 1883

144. Tekle Haymanot to Pasquale Stanislao Mancini

22 Nov. 1883

145. Minīlik II to Giulio Pestalozza

3 Dec. 1883

146. Mahammad Hanfadhē to Giulio Pestalozza

16 Dec. 1883

147. Welde Sadiq to Giulio Pestalozza

18 Dec. 1883

148. Mahammad Hanfadhē to Giulio Pestalozza

22 Dec. [1883]

149. Maḥammad Hanfadhē to Giovanni Branchi

24 Dec. 1883

150. Minīlik II to Pietro Antonelli

24 Dec. 1883

151. Maḥammad Hanfadhē to Giovanni Branchi

30 Dec. 1883

152. Mahammad Hanfadhē to Giovanni Branchi

28 Jan. 1884

153. Maḥammad Hanfadhē to Giovanni Branchi

5 Feb. 1884

154. Mahammad Hanfadhē to Giovanni Branchi

[March 1884]

155. Yohannis IV to Muhammad Tawfīq

14 March 1884

156. Yohannis IV to Muhammad Tawfīq

17 March 1884

157. Convention between Hamad La'îta and Italy

17 March 1884

158. Mahammad Hanfadhē to Giovanni Branchi

12 April 1884

159. Minillik II to Pietro Antonelli

8 May 1884

160. Mahammad Hanfadhē to Giovanni Branchi

8 May 1884

161. Welde Sadiq to Pietro Antonelli

22 May [1884]

162. Gobena Daçhī to Jules Grévy

[May-June 1884]

163. Minìlik II to Pietro Antonelli

1 June 1884

164. Minīlik II to Giulio Pestalozza

1 June 1884

165. Minīlik II to Umberto I

1 June 1884

166. Taytu to Margherita Maria Teresa Giovanna di Savoia

1 June 1884

167. Treaty between Ethiopia, Great Britain and Egypt

3 June 1884

168. Treaty between Ethiopia and Great Britain

3 June 1884

169. Maḥammad Hanfadhē to Giovanni Branchi

12 June 1884

170. Yosēf Nigusē to Pietro Antonelli

16 June 1884

171. Yohannis IV to Victoria

20 June 1884

172. Yohannis IV to Victoria

25 June 1884

173. Yohannis IV to Muhammad Tawfīq

25 June 1884

174. Yohannis IV to Giovanni Branchi

25 June 1884

175. Minīlik II to Giacomo Malvano

9 Aug. 1884

176. Minīlik II to Giovanni Branchi

9 Aug. 1884

177. Gebri'ēl Welde Gobena to Giacomo Malvano

9 Aug. 1884 
178. Minīlik II to Pietro Antonelli

9 Aug. 1884

179. Treaty between Hamad La'īta and France

9 Aug. 1884

180. Gīyorgīs Gebre Sillasē Nigusē to Pietro Antonelli

11 Aug. 1884

181. Yosēf Nigusē to Pietro Antonelli

[Aug. 1884]

182. Yohannis IV to Gebre Igzì'

10 Sept. 1884

183. Maḥammad Hanfadhē to Giulio Pestalozza

16 Sept. 1884

184. Treaty between Hamad Muḥammad and Léonce Lagarde

21 Sept. 1884

185. Mahammad Hanfadhē to Pasquale Stanislao Mancini

5 Oct. 1884

186. Mahammad Hanfadhē to Pasquale Stanislao Mancini

5 Oct. 1884

187. 'Abd al-Raḥmān Yūsif to Pasquale Stanislao Mancini

5 Oct. 1884

188. Hamad La'īta and 'Abd al-Qādir Ibrāhīm to Giulio Pestalozza

11 Oct. 1884

189. Mahammad Hanfadhē to Giulio Pestalozza

17 Oct. 1884

190. Donation by Hamad Muhammad et al. of territory to France

18 Oct. 1884

191. Minìlik II to Giulio Pestalozza

4 Nov. 1884

192. Yohannis IV to Welde Sema'it Welde Yohannis

5 Nov. 1884

193. Mahammad Hanfadhē to Giulio Pestalozza

11 Nov. 1884

194. Treaty between Hamad La'ìta and Italy

Nov. 1884

195. Yohannis IV to Welde Sema'it Welde Yohannis

22 Nov. 1884

196. Minīlik II to Umberto I

1 Dec. 1884

197. Minīlik II to Pasquale Stanislao Mancini

2 Dec. 1884

198. Donation by Hamad of Tajura and Hamad La'îta

14 Dec. 1884 
Sven Rubenson, Amsalu Aklilu, Shiferaw Bekele, and Samuel Shiferaw - 9789198469974 Downloaded from manchesterhive.com at 04/26/2023 11:50:20AM 